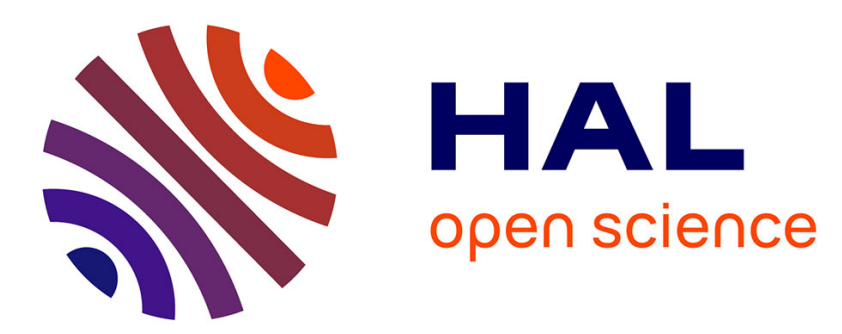

\title{
Organocatalytic Activation of Diethyl Glutaconate for the Diastereo- and Enantioselective Assembly of NH-Free 2,3,4-Trisubstituted Pyrrolidines
}

Adrien Quintard, Jean Rodriguez

\section{- To cite this version:}

Adrien Quintard, Jean Rodriguez. Organocatalytic Activation of Diethyl Glutaconate for the Diastereo- and Enantioselective Assembly of NH-Free 2,3,4-Trisubstituted Pyrrolidines . Organic Letters, 2017, 19 (3), pp.722-725. 10.1021/acs.orglett.7b00014 . hal-01533766

\section{HAL Id: hal-01533766 https://hal.science/hal-01533766}

Submitted on 6 Jun 2017

HAL is a multi-disciplinary open access archive for the deposit and dissemination of scientific research documents, whether they are published or not. The documents may come from teaching and research institutions in France or abroad, or from public or private research centers.
L'archive ouverte pluridisciplinaire HAL, est destinée au dépôt et à la diffusion de documents scientifiques de niveau recherche, publiés ou non, émanant des établissements d'enseignement et de recherche français ou étrangers, des laboratoires publics ou privés. 


\title{
Organocatalytic Activation of Diethyl Glutaconate for the Diastereo- and Enantioselective Assembly of NH-Free 2,3,4-Trisubstituted Pyrrolidines
}

\author{
Adrien Quintard*๑ and Jean Rodriguez
}

ABSTRACT: Organocatalyzed enantioselective consecutive Michael addition of diethyl glutaconate to a nitro-olefin/ reductive cyclization sequence has been developed, directly providing $\mathrm{NH}$-free trans,trans-2,3,4-trisubstituted pyrrolidines with typically $>88: 12 \mathrm{dr}$ and $>90 \%$ ee. The obtained structures are closely related to several molecules with high biological profiles, holding great promise for medicinal chemistry. In addition, their potential as direct organocatalysts in the enantioselective Michael addition promoted by enamine activation is also reported.

P rrolidines are unique heterocyclic scaffolds present in a broad range of biologically active molecules. ${ }^{1}$ In addition to this marked bioactivity, the pyrrolidine backbone has been abundantly used to build efficient chiral ligands and organocatalysts. ${ }^{2}$ Given the prevalence of this particular motif, the development of innovative direct enantioselective access to these structures from widely available substrates is highly desirable with strong potential for medicinal chemistry and catalytic applications.

Among the most straightforward and efficient routes to chiral pyrrolidines, $(3+2)$ cycloadditions notably catalyzed by copper complexes largely lead the way. Unfortunately, most of them provide products with substituents on both the 2- and 5positions of the pyrrolidine ring. ${ }^{3}$ This considerably limits the potential of these approaches because the 2,3,4-trisubstituted pyrrolidine chiral backbone is present in numerous highly biologically active molecules such as in kainic acid or endothelin receptors $\mathrm{ET}_{\mathrm{A}}$ antagonists shown in Scheme $1{ }^{4}$

Scheme 1. Proposed Strategy and Interest for

Enantioselective 2,3,4-Trisubstituted Pyrrolidines

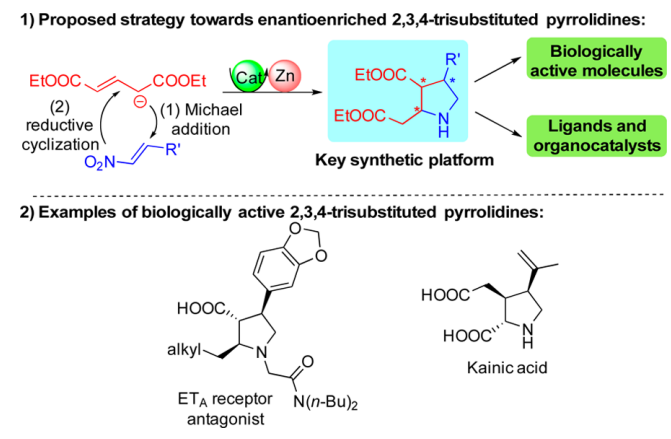

To develop an alternative rapid approach to this particular heterocyclic motif, we hypothesized that a new selective organocatalyzed (cat) dialkyl glutaconate addition to nitroolefins followed by a zinc-promoted reductive cyclization should efficiently provide the desired five-membered ring (Scheme 1). Among the main advantages of this methodology, the highly functionalized $\mathrm{NH}$-free pyrrolidines would be directly obtained without the requirement for any protecting groups and with two ester functions as well as an easily adjustable $\mathrm{R}^{\prime}$ group. As a result, the strategy should provide both a unique opportunity to access rapidly new drug leads and a powerful synthetic platform to build structurally different ligands or organocatalysts. ${ }^{5}$

The main challenge of developing such a strategy lies in the selective activation of the dialkyl glutaconate toward the designed nucleophilic addition. Indeed, to promote such condensation, the pro-nucleophile must be efficiently deprotonated at the $\alpha$ position of the ester due to the cooperation of the second ester through vinylogous delocalization. ${ }^{6}$ To our knowledge, the unique example of catalytic enantioselective activation of dialkyl glutaconates involved highly basic phase transfer catalysis. ${ }^{7}$ In 2009, the group of Bernardi and Fini showed that, under phase transfer catalysis, a cycloaddition with nitrones occurred, providing $\mathrm{N}-\mathrm{O}$ heterocycles such as isoxazolidines. While efficient, this strategy using aqueous base could hardly be applied to the proposed Michael addition, and alternatively, we hypothesized that bifunctional Brønsted base/acid catalysis might promote with success the proposed key vinylogous activation. ${ }^{8}$ Herein, we present our efforts at successfully developing this new enantioselective one-pot strategy and illustrate its synthetic interest by applying the obtained $\mathrm{NH}$ free pyrrolidines in aminocatalyzed Michael addition.

To develop the most straightforward access to chiral pyrrolidines, we focused our efforts on using commercially 
available diethyl glutaconate $\mathbf{1}$ and nitrostyrene $\mathbf{2 a}$ (Table 1). The reaction was best performed in $m$-xylene at $-20{ }^{\circ} \mathrm{C}$ using

Table 1. Optimization of the Pyrrolidine Synthesis

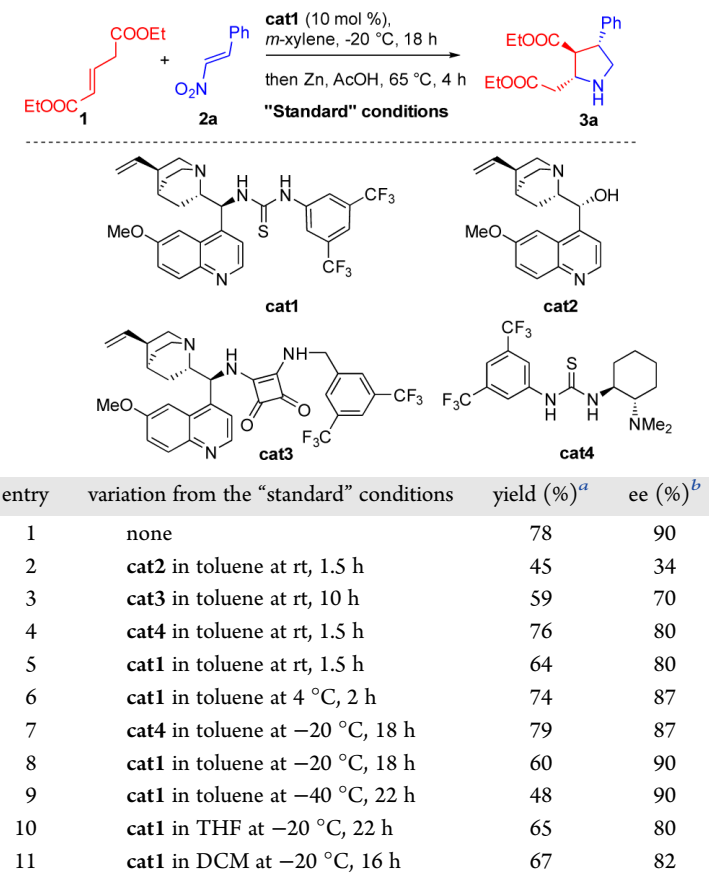

${ }^{a}$ Isolated yield after silica gel chromatography. ${ }^{b}$ Enantiomeric excess measured by HPLC in all cases for both diastereomers (90:10 dr for all entries).

bifunctional cat1. ${ }^{8 \mathrm{~b}}$ After completion of the Michael addition, acetic acid and $\mathrm{Zn}$ were directly added to the reaction mixture, providing cleanly the expected pyrrolidine $3 \mathrm{a}$ in $78 \%$ yield. In addition, the three newly created contiguous stereocenters were controlled in 90:10 dr and 90\% ee (Table 1, entry 1). ${ }^{9}$ When the reaction was performed at $\mathrm{rt}$ in toluene (Table 1 , entries $2-5$ ), among the organocatalysts tested, both cat 1 and cat 4 provided the best levels of enantiocontrol ( $80 \%$ ee); however, when the temperature was decreased to $4,-20$, or $-40{ }^{\circ} \mathrm{C}$ (Table 1 , entries $6-9)$, cat1 gave the best enantiocontrol $\left(90 \%\right.$ ee at $-20{ }^{\circ} \mathrm{C}$, Table 1 , entry 8 ). Finally, $m$-xylene allows the best reactivity and selectivity to be obtained, whereas other solvents, such as THF or dichloromethane, provided lower enantiocontrol (Table 1, entry 1 vs entries 10 and 11).

With these optimized conditions in hand, we then scrutinized the scope of the consecutive Michael addition/cyclization sequence (Scheme 2). Gratifyingly, a broad range of substitution patterns from functionalized aromatics to aliphatic chains were well-tolerated, providing the expected substituted pyrrolidines in usually good yields (42-84\% yield) and good stereocontrol (88:12 to $99: 1 \mathrm{dr}$ and 81 to $94 \%$ ee).

For example, a fluorinated aromatic, a thiophene, or a phenol could be incorporated with success, providing structures $\mathbf{3 b}-\mathbf{d}$. Starting from the nitro-olefin possessing a nitro-substitutent in the para-position of the aromatic, as expected, the corresponding aniline $3 \mathbf{e}$ was directly obtained with enantiocontrol decreased to $83 \%$. Insertion of electron-donating substituents $(\mathrm{OMe})$ yielded either $3 f$ ( $67 \%$ yield, $91 \%$ ee) or $3 \mathbf{h}$ ( $75 \%$ yield, $94 \%$ ee), with the
Scheme 2. Scope of the Enantioselective 2,3,4-Trisubstituted Pyrrolidines Synthesis

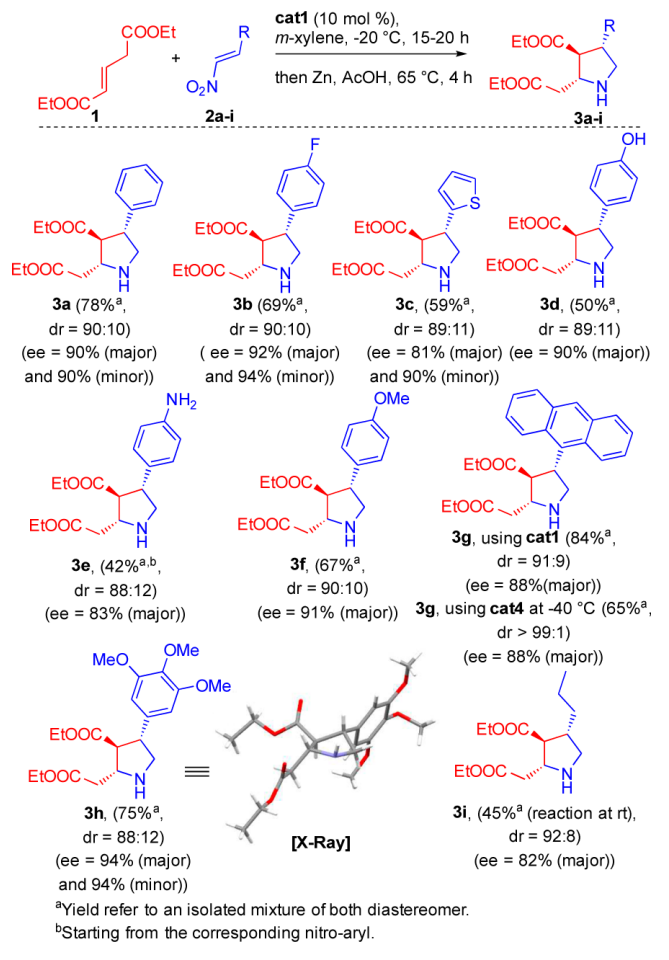

same good diastereocontrol around 90:10. The absolute configuration of pyrrolidine $3 \mathbf{h}$ was assigned as $(2 R, 3 S, 4 R)$ based on an X-ray crystallographic study, and the configurations of all other pyrrolidines were assigned accordingly. ${ }^{10}$ Incorporating sterically demanding anthracene was also possible, yielding $3 \mathrm{~g}$ in excellent $84 \%$ yield and good $88 \%$ ee. Interestingly, in this case, the initial 91:9 dr observed could be increased to $>99: 1 \mathrm{dr}$ by performing the reaction at $-40{ }^{\circ} \mathrm{C}$ with cat 4 .

Finally, an aliphatic nitroalkene could also be used efficiently in this sequence, even though the reaction had to be run at room temperature to obtain full conversion, and product $3 \mathbf{i}$ was formed in slightly decreased enantiocontrol ( $82 \%$ ee) with still high $92: 8$ dr.

Mechanistically, the final trans-2,3-diastereocontrol in the pyrrolidines seem to be fixed during the Michael addition, as shown by the difference in enantiocontrol observed between both diastereomers in molecules $3 \mathbf{b}$ and $3 \mathbf{c}$ and the diastereocontrol observed for the Michael adduct from 1 and $\mathbf{2 b}$ prior to reductive cyclization (see Supporting Information). This means that the cyclization (aza-Michael) creating the third stereocenter at C2 is totally trans-diastereoselective and under kinetic control because, for example, the $>99: 1 \mathrm{dr}$ in $3 \mathrm{~g}$ does not evolve upon prolonged time (Scheme 2).

To evaluate the practical applicability of this novel approach, reactions using $\mathbf{2 b}$ and $\mathbf{2 h}$ were conducted on the gram scale (Scheme 3). Interestingly, the catalyst loading could be reduced to $2 \mathrm{~mol} \%$ without noticeable loss of catalytic activity. Indeed, both products $\mathbf{3 b}$ and $\mathbf{3 h}$ were easily formed on the gram scale with more than $90 \%$ ee.

Given the rapid access to key NH-free pyrrolidine scaffolds, we were intrigued to test them as organocatalysts in enamine 
Scheme 3. Preparative Scale 2,3,4-Pyrrolidine Synthesis
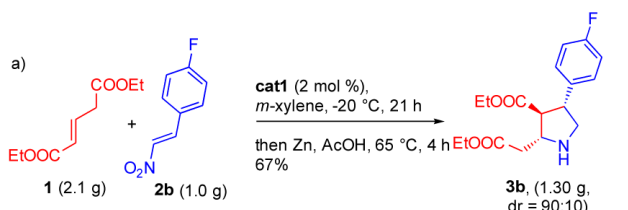

b) (ee $=90 \%$ (major) $)$

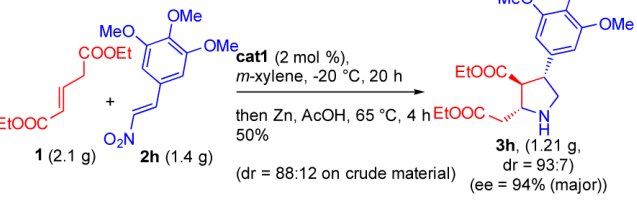

activation. Notably, given the spatial arrangement observed around the nitrogen atom, we felt that a good enantiodiscrimination should be observed in the Michael addition of carbonyl compounds to nitro-olefins. ${ }^{11}$ The library of pyrrolidines obtained in Scheme 2 was tested in the addition of cyclohexanone to nitrostyrene $2 \mathrm{a}$, and gratifyingly, among them, the anthracenyl derivative $3 \mathrm{~g}$ efficiently catalyzed the Michael addition (Scheme 4). ${ }^{12}$ Using $20 \mathrm{~mol} \%$ of $3 g$ with $88 \%$ ee, the

Scheme 4. Catalytic Application of the Obtained Pyrrolidine in Enamine Activation

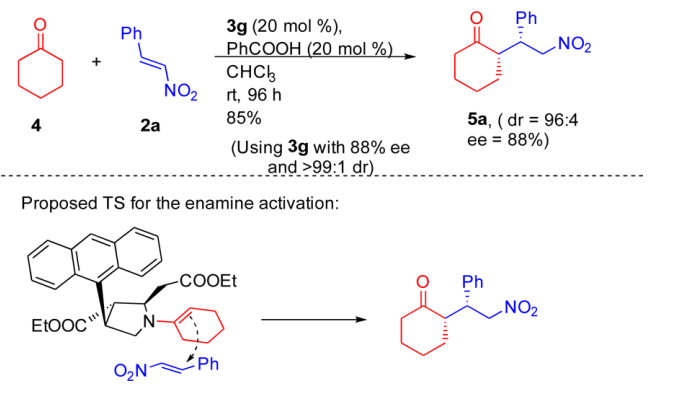

Michael adduct 5a was formed in 96:4 dr and 88\% ee, meaning that virtually a perfect enantiodiscrimination was observed in the transition state. The proposed transition state for this Michael addition involves the formation of the s-cis conformation of the $\mathrm{C}-\mathrm{N}$ single bond within the enamine (alkenyl substituent less hindered than the alkyl substituent), with addition to the electrophile from the less shielded bottom face. Higher enantiocontrol observed using the pyrrolidine $3 \mathrm{~g}$ possessing the anthracenyl substituent might possibly arise from a change in the conformation of the pyrrolidine, pushing the ester function to efficiently shield the upper face of the enamine (Scheme 4$){ }^{13}$

In conclusion, we have disclosed the first organocatalyzed condensation between diethyl glutaconate and nitro-olefins, allowing after in situ reductive cyclization the key chiral $\mathrm{NH}$-free trans,trans-2,3,4-trisubstituted pyrrolidines to be created with typically $>88: 12 \mathrm{dr}$ and $>90 \%$ ee. This consecutive reaction implies an innovative vinylogous-type activation of diethyl glutaconate that should readily find applications in the development of other enantioselective methods.

Given the close proximity of the obtained pyrrolidines with biologically active molecules possessing this motif, the developed approach bears some promise for the syntheses of therapeutic agents and should readily find applications in medicinal chemistry.

Finally, we have shown that the pyrrolidines directly accessed from our methodology could serve as efficient organocatalysts for enamine activation. This highly promising result opens new avenues to modify structurally the obtained heterocycles and potentially access new families of ligands and organocatalysts for enantioselective catalysis.

\section{ACKNOWLEDGMENTS}

The Agence Nationale pour la Recherche (ANR-13-PDOC0007-01), the Centre National de la Recherche Scientifique (CNRS), and the Aix-Marseille Université are gratefully acknowledged for financial support. The authors warmly thank Marion Jean and Nicolas Vanthuyne (Aix-Marseille UniversitéCNRS) for chiral-phase HPLC analysis. Michel Giorgi (AixMarseille Université-CNRS) is acknowledge for X-ray analysis of $3 \mathrm{~h}$.

\section{REFERENCES}

(1) Vitaku, E.; Smith, D. T.; Njardarson, J. T. J. Med. Chem. 2014, 57, 10257.

(2) (a) Bertelsen, S.; Jørgensen, K. A. Chem. Soc. Rev. 2009, 38, 2178.

(b) Melchiorre, P.; Marigo, M.; Carlone, A.; Bartoli, G. Angew. Chem., Int. Ed. 2008, 47, 6138

(3) For reviews, see: (a) Pandey, G.; Banerjee, P.; Gadre, S. R. Chem. Rev. 2006, 106, 4484. (b) Moyano, A.; Rios, R. Chem. Rev. 2011, 111, 4703. (c) Adrio, J.; Carretero, J. C. Chem. Commun. 2014, 50, 12434. (d) Han, M.-Y.; Jia, J.-Y.; Wang, W. Tetrahedron Lett. 2014, 55, 784 (e) Hashimoto, T.; Maruoka, K. Chem. Rev. 2015, 115, 5366. For examples of enantioselective 2,3,4-trisubstituted pyrrolidines synthesis, see: (f) Hernández-Toribio, J.; Padilla, S.; Adrio, J.; Carretero, J. C. Angew. Chem., Int. Ed. 2012, 51, 8854. (g) Pascual-Escudero, A. González-Esguevillas, M.; Padilla, S.; Adrio, J.; Carretero, J. C. Org. Lett. 2014, 16, 2228. (h) Jui, N. T.; Garber, J. A. O.; Finelli, F. G.; MacMillan, D. W. C. J. Am. Chem. Soc. 2012, 134, 11400. (i) Kumar, K.; KesavaReddy, N.; Golz, C.; Strohmann, C. Chem. - Eur. J. 2016, 22, 18373. (j) Næsborg, L.; Tur, F.; Meazza, M.; Blom, J.; Halskov, K. S.; Jørgensen, K. A. Chem. - Eur. J. 2017, 23, 268.

(4) See for example: (a) Abbott Laboratories. Patent Appl. WO1997030045Al, 1996. (b) Abbott Laboratories. Patent Appl. WO1999006397A2, 1997. (c) Boyd, S. A.; Mantei, R. A.; Tasker, A. S.; Liu, G.; Sorensen, B. K.; Henry, K. J., Jr.; von Geldern, T. W.; Winn, M.; Wu-Wong, J. R.; Chiou, W. J.; Dixon, D. B.; Hutchins, C. W.; Marsh, K. C.; Nguyen, B.; Opgenorth, T. J. Bioorg. Med. Chem. 1999, 7, 991. (d) Lynch, C. L.; Gentry, A. L.; Hale, J. J.; Mills, S. G.; MacCoss, M. Malkowitz, L.; Springer, M. S.; Gould, S. L.; DeMartino, J. A.; Siciliano, 
S. J.; Cascieri, M. A.; Doss, G.; Carella, A.; Carver, G.; Holmes, K.; Schleif, W. A.; Danzeisen, R.; Hazuda, D.; Kessler, J.; Lineberger, J.; Miller, M.; Emini, E. A. Bioorg. Med. Chem. Lett. 2002, 12, 677. (e) Murakami, S.; Takemoto, T.; Shimizu, Z. J. Pharm. Soc. Jpn. 1953, 73, 1026. (f) Nitta, I.; Watase, H.; Tomiie, Y. Nature 1958, 181, 761. (g) For a review on kainic acid synthesis, see: Stathakis, C. I.; Yioti, E. G.; Gallos, J. K. Eur. J. Org. Chem. 2012, 4661.

(5) For examples of catalytic enantioselective strategies providing access to pyrrolidine-type organocatalysts, see: (a) Ruiz-Olalla, A.; de Gracia Retamosa, M.; Cossio, F. P. J. Org. Chem. 2015, 80, 5588. (b) de Gracia Retamosa, M.; de Cózar, A.; Sánchez, M.; Miranda, J. I.; Sansano, J. M.; Castelló, L. M.; Nájera, C.; Jiménez, A. I.; Sayago, F. J.; Cativiela, C.; Cossio, F. P. Eur. J. Org. Chem. 2015, 2503.

(6) (a) Pansare, S. V.; Paul, E. K. Chem. - Eur. J. 2011, 17, 8770. (b) Bisai, V. Synthesis 2012, 44, 1453. (c) Jiang, H.; Albrecht, L.; Jørgensen, K. A. Chem. Sci. 2013, 4, 2287.

(7) Gioia, C.; Fini, F.; Mazzanti, A.; Bernardi, L.; Ricci, A. J. Am. Chem. Soc. 2009, 131, 9614.

(8) For a general review, see: (a) Connon, S. J. Chem. Commun. 2008, 2499. For the development of cat1, cat3, and cat4, see: (b) Vakulya, B.; Varga, S.; Csampai, A.; Soós, T. Org. Lett. 2005, 7, 1967. (c) Li, H.; Wang, Y.; Tang, L.; Wu, F.; Liu, X.; Guo, C.; Foxman, B. M.; Deng, L. Angew. Chem., Int. Ed. 2005, 44, 105. (d) Okino, T.; Hoashi, Y.; Takemoto, Y. J. Am. Chem. Soc. 2003, 125, 12672.

(9) Among all possible diastereomers of the pyrrolidines, only two were observed.

(10) The X-ray structure was deposited on the Cambridge database under the number CCDC 1518760 .

(11) For reviews, see: (a) Almasi, D.; Alonso, D. A.; Najera, C. Tetrahedron: Asymmetry 2007, 18, 299. (b) Tsogoeva, S. B. Eur. J. Org. Chem. 2007, 1701

(12) See Supporting Informations for results with other pyrrolidines.

(13) For related discussions, see: (a) Sulzer-Mossé, S.; Alexakis, A. Chem. Commun. 2007, 3123. (b) Quintard, A.; Langlois, J.-B.; Emery, D.; Mareda, J.; Guénée, L.; Alexakis, A. Chem. - Eur. J. 2011, 17, 13433. 